\title{
Emergence of Lyme Disease on Treeless Islands, Scotland, United Kingdom
}

\author{
Caroline Millins, Walter Leo, Isabell Maclnnes, Johanne Ferguson, Graham Charlesworth, \\ Donald Nayar, Reece Davison, Jonathan Yardley, Elizabeth Kilbride, Selene Huntley, \\ Lucy Gilbert, Mafalda Viana, Paul Johnson, Roman Biek
}

Lyme disease is usually associated with forested habitats but has recently emerged on treeless islands in the Western Isles of Scotland. The environmental and human components of Lyme disease risk in open habitats remain unknown. We quantified the environmental hazard and risk factors for human tick bite exposure among treeless islands with low and high Lyme disease incidence in the Western Isles. We found a higher prevalence of Borrelia burgdorferi sensu lato-infected ticks on high-incidence than on low-incidence islands $(6.4 \%$ vs. $0.7 \%$ ); we also found that residents of high-incidence islands reported increased tick bite exposure. Most tick bites $(72.7 \%)$ occurred $\leq 1 \mathrm{~km}$ from the home, including many in home gardens. Residents of high Lyme disease incidence islands reported increasing problems with ticks; many suggested changing deer distribution as a potential driver. We highlight the benefits of an integrated approach in understanding the factors that contribute to Lyme disease emergence.

$\mathrm{T}$ o optimize public health responses to vectorborne disease emergence, knowledge of the factors affecting the density of infected vectors in different habitats, human interactions with the environment that lead to vector exposure, and how these factors affect disease incidence are essential. Lyme disease, caused by infection with the bacterium Borrelia burgdorferi, is the most commonly reported vectorborne zoonotic disease in Europe and North America $(1,2)$. Higher densities of infected tick vectors (i.e.,

Author affiliations: University of Liverpool, Liverpool, UK

(C. Millins); University of Glasgow, Glasgow, Scotland, UK

(C. Millins, W. Leo, D. Nayar, R. Davison, J. Yardley, L. Gilbert,

M. Viana, P. Johnson, E. Kilbride, R. Biek); National Health

Service Western Isles, Benbecula, Scotland, UK (I. Maclnnes);

Scottish Natural Heritage, South Uist, Scotland, UK (J. Ferguson);

Southern Isles Veterinary Practice, Benbecula (G. Charlesworth);

Heb Insights, North Uist, Scotland, UK (S. Huntley)

DOI: https://doi.org/10.3201/eid2702.203862 environmental hazard) and Lyme disease incidence are associated with wooded habitats (3-5). However, the recent emergence of Lyme disease on treeless islands in Scotland (6), United Kingdom, has challenged the current understanding of the relationship between habitat and Lyme disease.

Lyme disease is an emerging zoonosis in the United Kingdom; the highest incidence is in the Highland region of Scotland $(7,8)$. In the United Kingdom, Lyme disease surveillance is based on laboratory confirmed cases, following the best practice guidelines for serologic diagnosis published by the National Institute for Health and Care Excellence (9-11). This surveillance shows that some islands in the Highland region that lack woodland coverage have a Lyme disease incidence $\approx 40$ times the national average (119 vs. 3.2 cases $/ 100,000$ persons per year) (6). These islands have had a higher Lyme disease incidence since at least 2010; other nearby, ecologically similar islands have a much lower incidence of 8.3 cases $/ 100,000$ persons (6). These islands also have a higher incidence of Lyme disease diagnoses made on the basis of an erythema migrans rash $(6,11)$. Knowledge of the factors affecting the density of infected ticks in the environment, how persons interact with the environment and are exposed to tick bites, and possible drivers of emergence is urgently needed to examine, predict, and mitigate Lyme disease emergence in treeless habitats.

Evidence suggests that Lyme disease hazard (measured as the density of infected ticks) is lower in treeless habitats than in wooded areas; however, much about this relationship remains unknown (12-18). Many experts consider woodlands to be the optimal habitat for the Ixodid tick vector because of the humid microclimate, which improves off-host tick survival and the density of potential hosts for blood meals $(12,13)$. Some studies have found lower tick densities in grassland than in nearby woodland habitats, prompting researchers to theorize that grassland might act as 
a sink for tick populations (14-16). Furthermore, many studies have found the density of the Ixodes ricinus tick, the main vector of Lyme disease in Europe, to be much lower in treeless habitats than woodlands (17). For example, surveys of open habitats in northern Spain found no questing I. ricinus ticks (18). In the United Kingdom, most studies have found relatively low tick densities in meadows (19), open hillside $(20,21)$, and heather moorland $(22,23)$.

The environmental hazard is linked to Lyme disease incidence through human interactions with the environment and exposure to infected tick bites (24). For example, a person's activities, knowledge of and attitude toward tickborne disease, and preventative behaviors will affect that person's risk for tick bites $(24,25)$. Analysis of where people are exposed to tick bites and risk factors for tick bite exposure can be used to guide preventive public health interventions (26).

In the absence of longitudinal environmental data in treeless areas, alternative approaches are needed to assess trends in tick population abundance and distribution. Tick populations in treeless habitats are affected by many of the same environmental drivers as those in forested areas, such as changes in climate, land management, and host density, especially deer populations (27-30). Surveys of local communities can provide information on whether the tick hazard is perceived to have changed over time. Responses might also suggest environmental factors associated with these changes (31).

To identify possible causes of Lyme disease emergence in treeless habitats, we assessed factors influencing tick density and prevalence of B. burgdorferi-infected ticks; geographic, demographic, and behavioral factors associated with human tick bite exposure; and community recollections of tick distribution and numbers over time. We used treeless islands with high and low Lyme disease incidence in the Western Isles in Scotland, United Kingdom, as our study system.

\section{Methods}

\section{Study Location and Site Selection}

We classified each island as having a low or high Lyme disease incidence based on Lyme disease surveillance data (6). We compared the environmental hazard between 26 sites on islands with high Lyme disease incidence (North Uist, South Uist, and Benbecula) and 16 sites on islands with low incidence (Harris and Barra). We selected sites belonging to 2 dominant habitat types: improved grassland (mesotrophic grasslands, often used for livestock grazing) and heather moorland (a mixture of wet heathland and western blanket bog) (32). We used a spatially stratified sampling design and the random selection tool in QGIS (QGIS Development Team, https:// www.qgis.org) to select sites (Figure 1). The vertebrate community of the Western Isles includes large ungulates, such as wild red deer (Cervus elaphus), farmed sheep, and cattle, all of which can maintain I. ricinus tick populations. The islands also have several B. burgdorferi sensu lato transmission hosts, including brown rats (Rattus norvegicus), Eurasian pygmy shrews (Sorex minutus), wood mice (Apodemus sylvaticus), hedgehogs (Erinaceus europaeus), field voles (Microtus agrestis), and certain species of passerine birds (33).

On islands where Lyme disease incidence is high (high-incidence islands), we also selected sites belonging to 3 additional habitats. We chose 8 sites in machair and 13 sites in bog and peatland habitats using the same stratified sampling approach. Machair is a sandy grassland along ocean coastline often used for grazing or cultivation (32). We also chose 12 sites in gardens that were randomly selected within each sector (Appendix Figure 1, https://wwwnc.cdc.gov/EID/article/27/2/20-3862App1.pdf). Sampling was carried out during the peak questing period for I. ricinus ticks. We conducted sampling during April 19-June 5, 2018. To strengthen the comparison of tick infection prevalence, we sampled additional sites in low Lyme disease incidence (lowincidence) areas during May 17-June 22, 2019.

\section{Tick Collection}

To estimate the density of questing I. ricinus ticks, we sampled from 20 randomized $10 \mathrm{~m}$ transects at each site. Transects were 30-50 m apart, or 20-30 m apart in gardens. We measured vegetation height and density, temperature, and humidity at the starting point of each transect (34). We dragged a $1 \mathrm{~m}^{2}$ white woolen blanket across the surface of the vegetation for 10 $\mathrm{m}$. We collected questing nymphs on the blanket, counted them, and placed them in 100\% ethanol. To increase the sample size, we carried out continuous blanket dragging for $\leq 2$ person-hours at each site.

\section{Screening of $I$. ricinus Ticks for B. burgdorferi s.I. and Genospecies Identification}

Our pilot study on South Uist in 2017 estimated that $6.6 \%$ of $I$. ricinus nymphs were infected with $B$. burgdorferi; we used this preliminary prevalence to estimate a target sample size of 50 nymphs/site (C. Millins, unpub. data). We used an ammonia hydroxide technique (35) to extract approximately 50 I. ricinus questing nymphs collected by blanket dragging 


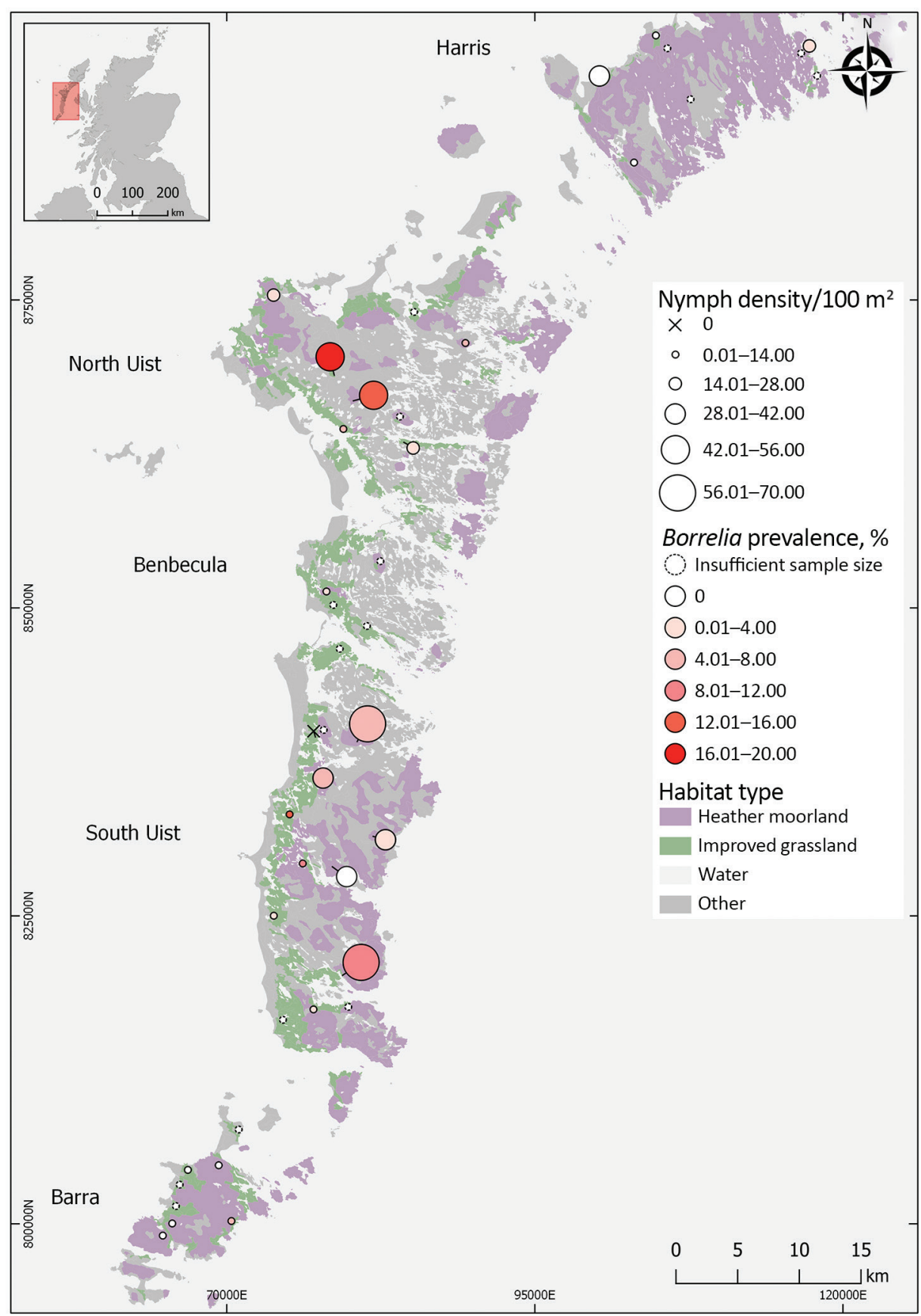

Figure 1. Tick collection sites for study on Lyme disease hazard, Western Isles, Scotland, UK, 2018-2019. Prevalence was not estimated at sites where $<50$ ticks were collected. Circle size indicates questing tick density. Circle color indicates Borrelia burgdorferi sensu lato prevalence. $\mathrm{X}$ indicates sites at which no ticks were detected.

at each site. We tested the ticks for B. burgdorferi s.l. infection using a nested PCR specific to the flagellin gene (36) with sequencing of the product to identify the genospecies.

\section{Geographic Locations of Human Tick Bite Exposure, Factors Associated with Tick Bite Risk, and Perceptions of Tick Problems Over Time}

We invited residents to complete a questionnaire about tick bite exposure. We used the survey to collect data about differences in tick bite exposure between islands with high and low Lyme disease incidence, habitat types where tick bites occurred, the distance of tick bites from the home address, and social and behavioral factors associated with exposure to tick bites. Residents were asked if problems with ticks had changed over time. The survey was approved by the University of Glasgow College of Medical, Veterinary \& Life Sciences Ethics Committee (reference no. 200170121). The survey was available online 
and in paper copy during April 18-October 31, 2018, and was publicized in local media and at community meetings.

\section{Statistical Analysis}

We conducted statistical analyses and model selection in $\mathrm{R}$ version 4.0 .0 (https://www.r-project.org) using the lme4 package for generalized linear mixed models (GLMMs) (37). We tested for correlations between explanatory variables using the variance inflation function in the car package (38). We tested each model for overdispersion. Starting from the maximum global model, we conducted stepwise model selection using likelihood-ratio tests (39).

Because Lyme disease incidence is reported at the island level (6), we assessed the relationship with the environmental hazard using a 2-step process. First, we investigated island as a predictor of nymph density, nymph infection prevalence, and the density of infected nymphs. Then, we made betweenisland comparisons from the best fit model using the Tukey test in the lsmeans package (40). We modeled nymph abundance (i.e., number of nymphs/10 m transect) from sites sampled in 2018 using a Poisson GLMM with a log link as a function of island, habitat type and wind (using the Beaufort wind force scale), vegetation density, temperature, and humidity with random effects of site and observation (41). We modeled the proportion of nymphs infected with B. burgdorferi s.l. from sites sampled in 2018 and 2019 using a binomial GLMM with a logit link as a function of island, habitat type, and mean nymph density with a random effect of site. We modeled the density of infected nymphs as the number of infected nymphs using a Poisson GLMM with a log link as a function of island and habitat, with an offset of the log estimated area to collect nymphs tested, using a random effect of site.

For high-incidence islands, where we had sampled additional habitat types, we used separate GLMM models to test for the effect of habitat and island on nymph density, nymph infection prevalence, and the density of infected nymphs. We did not include machair in the analyses because of the low number of nymphs detected.

We used survey responses to test for differences in human exposure to tick bites among islands with high and low Lyme disease incidence. We received 522 surveys from adult residents of the Western Isles, representing approximately $2 \%$ of the adult population. According to local census data, survey responses were broadly representative of island populations (Appendix). We modeled risk for tick bite exposure, classified as high ( $\geq 5$ tick bites/year) or low ( $<5$ tick bites/year), using univariable analysis (Appendix Table 1) and then with a binomial GLM and a logit link as a function of island of residence, age, sex, frequency of outdoor activity, and pet ownership. Because awareness, attitudes and preventative behavior relating to tickborne disease could influence reported tick bite exposure, we tested for associations between risk for tick bite exposure and these explanatory variables in a separate model with an interaction of each variable with Lyme disease incidence.

Survey respondents commonly reported ticks in the home; we hypothesized that ticks could be transported indoors by clothing or pets and that this kind of exposure could vary among islands. To test this hypothesis, we used a binomial GLM and a logit link to model whether any tick (live and unfed, engorged, or dead) had ever been detected inside the home as a function of island, level of outdoor activity, and pet ownership.

We hypothesized that a higher proportion of respondents from high-incidence islands would report increasing tick numbers and associated problems than respondents from low Lyme disease incidence islands. We categorized free text responses as increased or not increased and used a binomial GLM with a logit link using Lyme disease incidence as an explanatory variable. We compared free text responses among residents of high- and low-incidence islands to assess factors associated with problems related to ticks. We used a corpus linguistic approach to extract common keywords and associated clusters of words for comparison (42; Appendix)

\section{Results}

\section{Nymph Density}

Nymph density did not vary significantly between islands with high and low Lyme disease incidence; island was not retained as an explanatory variable in the best fit model (Table $1 ; \chi^{2}=3.15$; degree of freedom $[\mathrm{df}]=4 ; p=0.53$ ) (Figure 2). In 2018, mean nymph density at improved grassland and heather moorland sites on low Lyme disease incidence islands was 1.36 nymphs $/ 10 \mathrm{~m}^{2}(\mathrm{SE}=0.28)$ compared to 1.60 nymphs $/ 10 \mathrm{~m}^{2}$ (SE $\left.=0.25\right)$ on high-incidence islands (Figure 1; Appendix Table 2).

For sites sampled among different habitat types on high Lyme disease incidence islands (Appendix Figure 1), the best fit model to predict nymph density retained habitat type as a fixed effect $\left(\chi^{2}=24.06\right.$; $\mathrm{df}=4 ; \mathrm{p}<0.01$ ) (Figure 3; Appendix Table 3). We found significantly fewer nymphs in machair than in other 
Table 1. Best-fit generalized linear mixed models of nymph density, Borrelia burgdorferi sensu lato prevalence, and density of infected nymphs among questing Ixodes ricinus ticks, Western Isles, Scotland, UK, 2018-2019

\begin{tabular}{|c|c|c|c|c|}
\hline Response variable & Explanatory variable & Estimate & SE & $p$ value ${ }^{*}$ \\
\hline \multirow[t]{2}{*}{ Nymph density } & Intercept & -4.02 & 0.93 & \\
\hline & Temperature, ${ }^{\circ} \mathrm{C} / 10$ & 2.11 & 0.64 & $<0.01$ \\
\hline \multirow[t]{6}{*}{ Nymph infection prevalence } & Intercept & -2.94 & 0.30 & \\
\hline & Island & & & $<0.01$ \\
\hline & South Uist & Referent & & \\
\hline & North Uist & 0.37 & 0.44 & \\
\hline & Harris & -2.69 & 1.11 & \\
\hline & Barra & -1.98 & 0.71 & \\
\hline \multirow{6}{*}{ Density of infected nymphs } & Intercept & -4.82 & 0.52 & \\
\hline & Island & & & $<0.01$ \\
\hline & South Uist & Referent & & \\
\hline & North Uist & -0.07 & 0.79 & \\
\hline & Harris & -2.96 & 1.45 & \\
\hline & Barra & -4.07 & 1.15 & \\
\hline
\end{tabular}

habitat types ( $\mathrm{p}<0.01$ by Tukey post hoc analysis); we found no significant differences in nymph density between other habitat types.

\section{B. burgdorferi s.I. Nymph Infection Prevalence}

We found that the prevalence of B. burgdorferi s.l. infection was significantly associated with island (Table $1 ; \chi^{2}=17.04 ; \mathrm{df}=3 ; \mathrm{p}<0.01$ ) (Figure 2). In total, 3 of 4 between-island comparisons showed that prevalence was significantly higher on high-incidence than on low-incidence islands. We found no significant differences in prevalence between islands with the same level of Lyme disease incidence (Appendix Table 4).

The mean infection prevalence on high-incidence islands $(6.43 \% ; 57 / 886 ; \mathrm{SE}=0.82)$ was higher than on low-incidence islands $(0.66 \% ; 4 / 609$; SE $=0.33)$ (Appendix Table 2). Among sites on high-incidence islands, $98.25 \%(56 / 57)$ of infected nymphs carried B. afzelii and $1.75 \%(1 / 57)$ carried B. garinii. Among sites on low-incidence islands, $75 \%(3 / 4)$ of infected nymphs carried B. garinii and $25 \%(1 / 4)$ carried B. valaisiana. Among sites on high-incidence islands, prevalence did not differ by island or habitat type (Appendix Table 3).

\section{Density of Infected Nymphs}

Variation in the density of infected nymphs was significantly associated with island (Table $1 ; \chi^{2}=16.98$; $\mathrm{df}=3 ; \mathrm{p}<0.01$ ) (Figure 2). In 2 of 4 between-island comparisons, the density of infected nymphs was significantly higher on high-incidence than on lowincidence islands. We found no significant differences between islands with the same level of Lyme disease incidence (Appendix Table 4).

The mean density of infected nymphs was 1.90 nymphs $/ 100 \mathrm{~m}^{2}(\mathrm{SE}=0.65)$ on high Lyme disease incidence islands, compared with 0.07 infected nymphs $/ 100 \mathrm{~m}^{2}(\mathrm{SE}=0.05)$ on low-incidence islands. Among sites on high-incidence islands, the density of infected nymphs did not differ by island or habitat type (Appendix Table 3).

\section{Geographic Locations of Tick Bite Risk}

Most $(64.4 \%$; 333/517) participants provided information on their island of residence and the habitat where their most recent tick bite had occurred (Appendix). In addition, $51.7 \%(172 / 333)$ of these participants also provided the location of their most recent tick bite. Of these bites, $72.7 \%(125 / 172)$ occurred within $1 \mathrm{~km}$ of
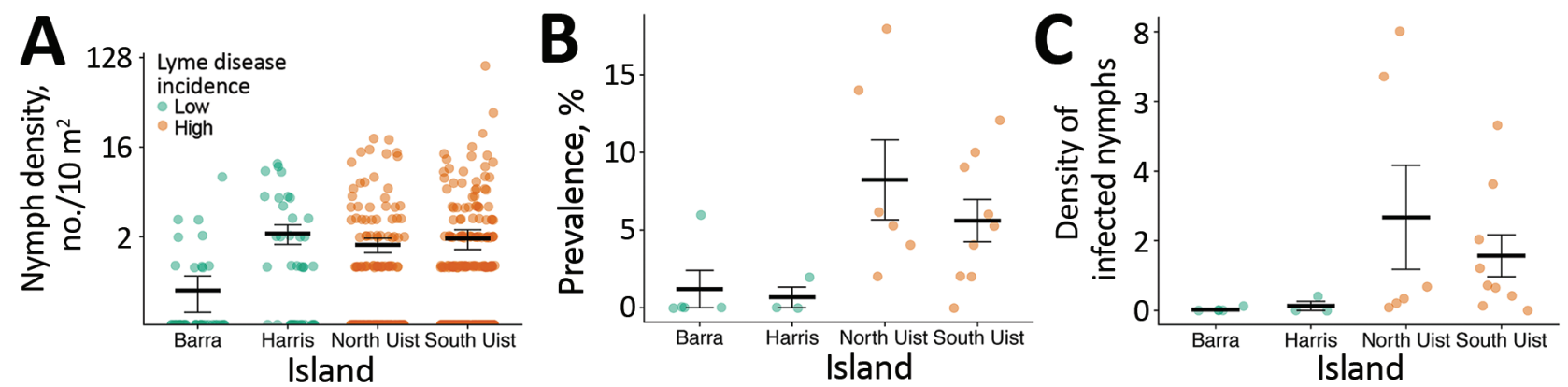

Island

Figure 2. Comparison of nymph density, infection prevalence, and density of infected nymphs by island, Western Isles, Scotland, UK, 2018-2019. A) Nymph density shown by $10 \mathrm{~m}^{2}$ blanket drag. B) Prevalence of Borrelia burgdorferi sensu lato shown by site. C) Density of infected nymphs per $100 \mathrm{~m}^{2}$ shown by site. Green indicates islands with low incidence of Lyme disease; brown indicates islands with high incidence. Data shown from grassland and moorland sites shown in Figure 1. Horizontal bars indicate means and SEs. 
Table 2. Best-fit general linear model of factors affecting risk for tick bite exposure in residents of the Western Isles, Scotland, UK, 2018-2019

\begin{tabular}{|c|c|c|c|c|}
\hline Variable & Estimate & SE & $p$ value* & Odds ratio $(95 \% \mathrm{Cl})$ \\
\hline Intercept & -1.99 & 0.54 & NA & NA \\
\hline Island & & & $<0.01$ & \\
\hline South Uist & Referent & & & \\
\hline North Uist & 0.11 & 0.31 & & $1.12(0.61-2.07)$ \\
\hline Benbecula & -0.85 & 0.48 & & $0.43(0.16-1.05)$ \\
\hline Barra & 0.01 & 0.42 & & $1.01(0.43-2.30)$ \\
\hline Harris/Lewis & -1.14 & 0.33 & & $0.32(0.16-0.61)$ \\
\hline Age, y & & & 0.01 & \\
\hline $18-30$ & Referent & & & \\
\hline $30-60$ & 0.76 & 0.48 & & $2.14(0.90-5.97)$ \\
\hline$>60$ & 1.36 & 0.51 & & $3.88(1.50-11.48)$ \\
\hline Outdoor activity & & & 0.02 & \\
\hline Less than most days & Referent & & & \\
\hline Most days & 0.66 & 0.29 & & $1.94(1.12-3.49)$ \\
\hline
\end{tabular}

the participant's home address, including 81 (47.1\%) at the home address (Appendix Figure 2).

\section{Factors Associated with Tick Bite Exposure Risk}

In a multivariable model, the most significant explanatory variable for tick bite exposure risk was island of residence $\left(\chi^{2}=20.86 ; \mathrm{df}=4 ; \mathrm{p}<0.01\right)$ (Table $2)$. Persons $>60$ years of age had an increased risk for tick bite exposure (odds ratio [OR] 3.88, 95\% CI 1.50-11.48). Persons who participated in outdoor activity most days also had an increased risk for tick bite exposure (OR 1.94, 95\% CI 1.12-3.49). Residents of high Lyme disease incidence islands had significantly higher rates of tick bite exposure than those of low Lyme disease incidence islands (OR 2.41, 95\% CI 1.55-3.82; Appendix Table 1). Awareness, attitudes, and preventative behaviors did not significantly differ between residents living on islands of high and low Lyme disease incidence.

Factors Associated with Finding a Tick within the Home The chances of finding a tick within the home increased with pet ownership (OR 4.07, 95\% CI 2.61-6.41).
Persons who participated in outdoor activity most days also had a slightly increased risk (OR 1.67, 1.052.64). The likelihood of finding a tick in the home did not vary among islands (Appendix Table 5).

\section{Changes in Tick Numbers and Problems Over Time}

Approximately half $(50.6 \% ; 210 / 415)$ of respondents described an increase in tick-associated problems over time. Residents from high Lyme disease incidence islands were significantly more likely to report that tick numbers and associated problems had increased over time (OR 4.5, 95\% CI 2.1-10.0) $\left(\chi^{2}=15.48 ; \mathrm{df}=1\right.$; $\mathrm{p}<0.01$ ) (Appendix Table 6). Linguistic analysis of free text comments revealed differences in themes between high and low Lyme disease incidence islands. Residents throughout the surveyed area reported an increased tick presence; residents of high Lyme disease incidence islands were more likely to describe the increase with words such as definitely or significantly than residents of low Lyme disease incidence islands. Residents of high Lyme disease incidence islands were also more likely to report deer near their homes (Appendix Table 7).
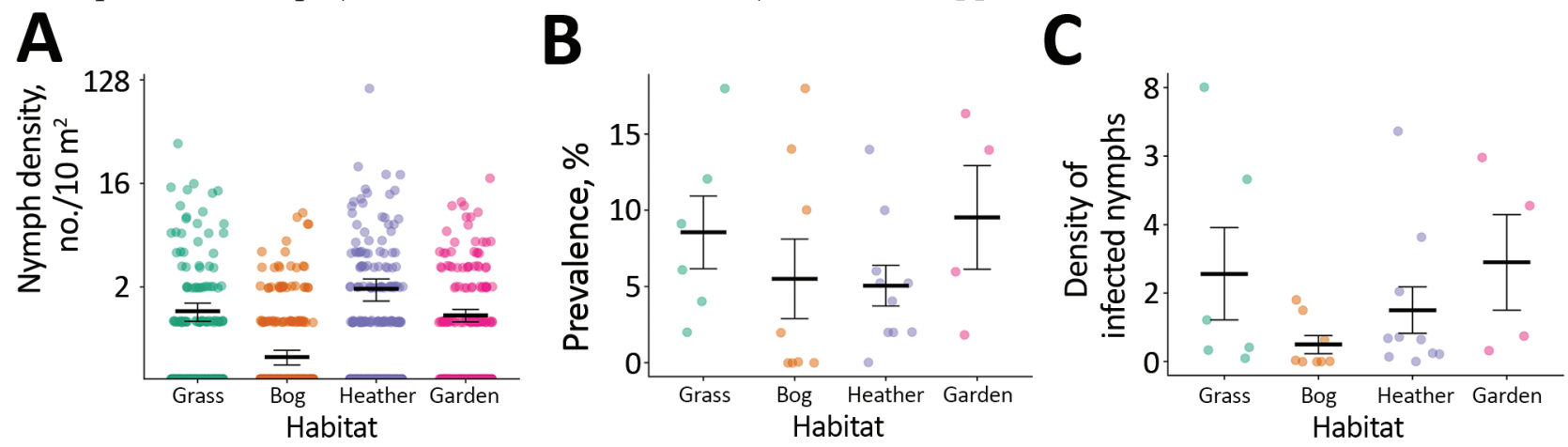

Figure 3. Comparison of nymph density, infection prevalence, and density of infected nymphs by habitat type in islands with high incidence of Lyme disease, Western Isles, Scotland, UK, 2018. A) Nymph density shown by $10 \mathrm{~m}^{2}$ blanket drag. B) Prevalence of Borrelia burgdorferi sensu lato shown by site. C) Density of infected nymphs per $100 \mathrm{~m}^{2}$ shown by site. Machair sites not shown because of low mean tick density $\left(0.025\right.$ nymphs $/ 10 \mathrm{~m}^{2}$; SE $\left.=0.015\right)$. Horizontal bars indicate means and SEs. 


\section{Discussion}

We investigated Lyme disease emergence in treeless habitats in Scotland. Our findings show that environmental hazard and human tick bite exposure risk contribute to higher Lyme disease incidence in these settings. In contrast to previous studies in Europe, we found that the density of infected nymphs in treeless habitats can be comparable to forested sites, which are traditionally associated with higher Lyme disease hazard $(34,43)$.

We found a significantly higher prevalence of $B$. burgdorferi s.l. infected nymphs among high Lyme disease incidence islands, which contributed to a higher environmental hazard on these islands. Almost all infected ticks on these islands carried B. afzelii, a genospecies associated with mammalian transmission hosts (44). We did not detect $B$. afzelii infection in ticks collected from low Lyme disease incidence islands, where the prevalence of infection in ticks was extremely low $(<1 \%)$. Because of the similarity in habitats and climate, we hypothesize that the presence or absence of this genospecies could be driven by differences in the host community. Alternatively, the introduction of $B$. afzelii from the mainland might have been limited to certain islands.

Within islands with a high incidence of Lyme disease, we found that improved grassland, heather moorland, bog and peatland, and domestic gardens had similar tick density and prevalence of $B$. burgdorferi s.l. infection among ticks as forested mainland sites in Scotland $(34,43)$. Our results suggest that microclimatic conditions in these open habitats, possibly driven by the milder oceanic climate on the Western Isles, can be as conducive to tick survival as conditions in woodlands. Tick abundance was positively associated with vegetation density, which when combined with relatively high rainfall and humidity in this location, might contribute to a favorable microclimate and improved off-host tick survival. In contrast, we found significantly lower tick abundance within machair grassland, probably caused by a combination of short vegetation height, lack of a vegetation mat, and agricultural rotations and ploughing, which can reduce off-host tick survival $(45,46)$. Tick abundance varied considerably within habitats (Appendix Table 2), a finding that warrants further investigation.

In addition to a higher environmental hazard on high Lyme disease incidence islands, residents of these islands reported more frequent exposures to tick bites. Tick bite exposure increased with the participant's age and amount of outdoor activity. Although outdoor activity and knowledge, attitudes, and prevention of tick bites did not contribute to differences in tick bite exposure between islands with high and low Lyme disease incidence, this finding might have been affected by the higher proportion of responses from older residents on high Lyme disease incidence islands. Although we found no significant differences in tick density between high- and low-incidence grassland and moorland sites, survey responses indicated that most tick bites occurred close to the home address, and frequently in gardens. On high Lyme disease incidence islands, we found a similar density of infected nymphs in gardens to surrounding habitats, indicating that spillover of infected ticks is common. Further research is required to test whether peridomestic tick exposure contributes to differences in tick bite exposure between islands. The findings that tick bites frequently occur within gardens and that residents might be exposed to ticks within their homes suggest that all members of a household could be at risk for tick bites. Our research suggests that environmental and educational public health interventions focused around residences could reduce tick bite exposure and potentially cases of Lyme disease.

Similar to previous studies, we found that in the absence of longitudinal data on vector populations and linked ecologic drivers, community surveys can be valuable indicators of ecologic trends (31). Residents of high Lyme disease incidence islands were significantly more likely to report that ticks were an increasing problem. In addition, many of these participants suggested that increased deer populations and presence near homes might contribute to increased numbers of ticks. Because deer habitat use and movements are established drivers of tick populations and distribution $(27,47,48)$ and are associated with Lyme disease emergence in other areas of Europe (49), this association should be investigated in future research.

In summary, we have shown that treeless habitats can support similar tick densities and infection risk as forested areas and can be associated with Lyme disease emergence in humans. Our results suggest the potential for Lyme disease to emerge in open habitats with a suitable microclimate for off-host tick survival and host availability for blood meals elsewhere in Europe. Integrating these results with data on human exposure to tick bites revealed that most tick bites occurred close to homes. Furthermore, we found that the spillover of ticks and tickborne pathogens into gardens and homes is an emerging problem that residents attribute to increased deer populations and their changing distribution. Further research to understand the effects of ecologic drivers of tick populations in these regions, together with information on human use of these environments, is necessary to achieve more accurate prediction of areas of risk and suggest ways to prevent and mitigate this risk. 


\section{Acknowledgments}

We thank 2 anonymous reviewers for their helpful comments on the manuscript.

M.V. was funded by the European Research Council under the European Union's Horizon 2020 Research and Innovation Programme (grant agreement no. 852957). J.Y. was supported by a Collaborative Awards in Science and Engineering studentship funded by the Natural Environment Research Council, Swindon, UK.

\section{About the Author}

Dr. Millins is a research fellow at the University of Liverpool. Her primary research interests include One Health approaches to the study of zoonotic pathogens, vectorborne pathogen ecology, and wildlife health.

\section{References}

1. Dennis D, Hayes E. Epidemiology of Lyme borreliosis. In: Gray J, Kahl O, Lane R, Stanek G, editors. Lyme borreliosis: biology, epidemiology and control. New York: CABI; 2002. p. 251-80.

2. Rizzoli A, Hauffe H, Carpi G, Vourc H G, Neteler M, Rosà R. Lyme borreliosis in Europe. Euro Surveill. 2011;16:19906.

3. James MC. The ecology, genetic diversity and epidemiology of Lyme borreliosis in Scotland [PhD thesis]. Aberdeen (UK): University of Aberdeen; 2010.

4. Eisen RJ, Lane RS, Fritz CL, Eisen L. Spatial patterns of Lyme disease risk in California based on disease incidence data and modeling of vector-tick exposure. Am J Trop Med Hyg. 2006;75:669-76. https://doi.org/10.4269/ajtmh.2006.75.669

5. Dister SW, Fish D, Bros SM, Frank DH, Wood BL. Landscape characterization of peridomestic risk for Lyme disease using satellite imagery. Am J Trop Med Hyg. 1997;57:687-92. https://doi.org/10.4269/ajtmh.1997.57.687

6. National Health Service-Western Isles. The 'tick'-ing time bomb: the incidence of Lyme disease in the Outer Hebrides (2010-2017). 2018 [cited 2020 Aug 13]. https://www.wihb.scot.nhs.uk/wp-content/uploads/2020/08/A0-Template-The-ticking-time-bomb.Incidence-of-Lyme-disease-in-the-Western-Isles-2010-2017.pdf

7. Slack GS, Mavin S, Yirrell D, Ho-Yen DO. Is Tayside becoming a Scottish hotspot for Lyme borreliosis? J R Coll Physicians Edinb. 2011;41:5-8. https://doi.org/10.4997/ JRCPE.2011.102

8. Tulloch JSP, Decraene V, Christley RM, Radford AD, Warner JC, Vivancos R. Characteristics and patient pathways of Lyme disease patients: a retrospective analysis of hospital episode data in England and Wales (1998-2015). BMC Public Health. 2019;19:931. https:/ / doi.org/10.1186/ s12889-019-7245-8

9. Mavin S, Watson EJ, Evans R. Distribution and presentation of Lyme borreliosis in Scotland - analysis of data from a national testing laboratory. J R Coll Physicians Edinb. 2015;45:196-200. https://doi.org/10.4997/JRCPE.2015.304

10. Tulloch JSP, Semper AE, Brooks TJG, Russell K, Halsby KD, Christley RM, et al. The demographics and geographic distribution of laboratory-confirmed Lyme disease cases in England and Wales (2013-2016): an ecological study. BMJ Open. 2019;9:e028064. https:/ / doi.org/10.1136/ bmjopen-2018-028064
11. National Institute for Health and Care Excellence. Lyme disease. 2018 [cited 2020 Oct 20]. https:/ / www.nice.org.uk/ guidance/ng95

12. Medlock JM, Shuttleworth H, Copley V, Hansford KM, Leach S. Woodland biodiversity management as a tool for reducing human exposure to Ixodes ricinus ticks: a preliminary study in an English woodland. J Vector Ecol. 2012;37:307-15. https://doi.org/10.1111/ j.1948-7134.2012.00232.x

13. Randolph SE. Tick ecology: processes and patterns behind the epidemiological risk posed by Ixodid ticks as vectors. Parasitology. 2004;129:S37-65. https:/ / doi.org/10.1017/ S0031182004004925

14. Boyard C, Barnouin J, Gasqui P, Vourc'h G. Local environmental factors characterizing Ixodes ricinus nymph abundance in grazed permanent pastures for cattle. Parasitology. 2007;134:987-94. https://doi.org/10.1017/ S0031182007002351

15. Hoch T, Monnet $Y$, Agoulon A. Influence of host migration between woodland and pasture on the population dynamics of the tick Ixodes ricinus: a modelling approach. Ecol Modell. 2010;221:1798-806. https://doi.org/10.1016/j.ecolmodel. 2010.04.008

16. Gilbert L. How landscapes shape Lyme borreliosis risk. In: Braks M, van Wieren SE, Takken W, Sprong H, editors. Ecology and control of vector borne diseases. Vol 4. Wageningen, the Netherlands: Wageningen Academic Publishers; 2016. p. 161-71.

17. Gray JS, Kahl O, Robertson JN, Daniel M, Estrada-Peña A, Gettinby G, et al. Lyme borreliosis habitat assessment. Zentralbl Bakteriol. 1998;287:211-28. https:/ / doi.org/ 10.1016/S0934-8840(98)80123-0

18. Estrada-Peña A. Distribution, abundance, and habitat preferences of Ixodes ricinus (Acari: Ixodidae) in northern Spain. J Med Entomol. 2001;38:361-70. https:/ / doi.org/ 10.1603/0022-2585-38.3.361

19. Gray JS. The ecology of ticks transmitting Lyme borreliosis. Exp Appl Acarol. 1998;22:249-58. https:/ / doi.org/ 10.1023/ A:1006070416135

20. Ogden NH, Nuttall PA, Randolph SE. Natural Lyme disease cycles maintained via sheep by co-feeding ticks. Parasitology. 1997;115:591-9. https://doi.org/10.1017/S0031182097001868

21. Walker AR, Alberdi MP, Urquhart KA, Rose H. Risk factors in habitats of the tick Ixodes ricinus influencing human exposure to Ehrlichia phagocy tophila bacteria. Med Vet Entomol. 2001;15:40-9. https:/ / doi.org/10.1046/ j.1365-2915.2001.00271.x

22. Ruiz-Fons F, Gilbert L. The role of deer as vehicles to move ticks, Ixodes ricinus, between contrasting habitats. Int J Parasitol. 2010;40:1013-20. https:/ / doi.org/10.1016/ j.ijpara.2010.02.006

23. Harrison A, Newey S, Gilbert L, Haydon DT, Thirgood S. Culling wildlife hosts to control disease: mountain hares, red grouse and louping ill virus. J Appl Ecol. 2010;47:926-30. https://doi.org/10.1111/j.1365-2664.2010.01834.x

24. Bouchard C, Aenishaenslin C, Rees EE, Koffi JK, Pelcat $Y$, Ripoche M, et al. Integrated social-behavioral and ecological risk maps to prioritize local public health responses to Lyme disease. Environ Health Perspect. 2018;126:047008. https://doi.org/10.1289/EHP1943

25. Fischhoff IR, Keesing F, Ostfeld RS. Risk factors for bites and diseases associated with black-legged ticks: a meta-analysis. Am J Epidemiol. 2019;188:1742-50. https:// doi.org/10.1093/ aje/kwz130

26. Finch C, Al-Damluji MS, Krause PJ, Niccolai L, Steeves $\mathrm{T}, \mathrm{O}^{\prime}$ Keefe CF, et al. Integrated assessment of behavioral 
and environmental risk factors for Lyme disease infection on Block Island, Rhode Island. PLoS One. 2014;9:e84758. https:/ / doi.org/10.1371/journal.pone.0084758

27. Medlock JM, Hansford KM, Bormane A, Derdakova M, Estrada-Peña A, George J-C, et al. Driving forces for changes in geographical distribution of Ixodes ricinus ticks in Europe. Parasit Vectors. 2013;6:1. https:/ / doi.org/10.1186/ 1756-3305-6-1

28. Werden L, Barker IK, Bowman J, Gonzales EK, Leighton PA, Lindsay LR, et al. Geography, deer, and host biodiversity shape the pattern of Lyme disease emergence in the Thousand Islands Archipelago of Ontario, Canada. PLoS One. 2014;9:e85640. https://doi.org/10.1371/journal. pone. 0085640

29. Ostfeld RS, Brunner JL. Climate change and Ixodes tick-borne diseases of humans. Philos Trans R Soc Lond B Biol Sci. 2015;370:20140051. https://doi.org/10.1098/rstb.2014.0051

30. Simon JA, Marrotte RR, Desrosiers N, Fiset J, Gaitan J, Gonzalez A, et al. Climate change and habitat fragmentation drive the occurrence of Borrelia burgdorferi, the agent of Lyme disease, at the northeastern limit of its distribution. Evol Appl. 2014;7:750-64. https://doi.org/10.1111/eva.12165

31. Kimaro EG, Toribio JLML, Mor SM. Climate change and cattle vector-borne diseases: use of participatory epidemiology to investigate experiences in pastoral communities in Northern Tanzania. Prev Vet Med. 2017;147:79_ 89. https://doi.org/10.1016/j.prevetmed.2017.08.010

32. Angus $S$. The Outer Hebrides: moor and machair. Winwick (UK): White Horse Press; 2001. p. 78-81, 200.

33. National Biodiversity Network Atlas Partnership. National biodiversity network atlas. 2017 [cited 2020 Jul 1]. https:/ / records.nbnatlas.org

34. Millins C, Gilbert L, Johnson P, James M, Kilbride E, Birtles R, et al. Heterogeneity in the abundance and distribution of Ixodes ricinus and Borrelia burgdorferi (sensu lato) in Scotland: implications for risk prediction. Parasit Vectors. 2016;9:595. https://doi.org/10.1186/ s13071-016-1875-9

35. Gern L, Douet V, López Z, Rais O, Cadenas FM. Diversity of Borrelia genospecies in Ixodes ricinus ticks in a Lyme borreliosis endemic area in Switzerland identified by using new probes for reverse line blotting. Ticks Tick Borne Dis. 2010;1:23-9. https:/ / doi.org/10.1016/j.ttbdis.2009.11.001

36. Johnson BJB, Happ CM, Mayer LW, Piesman J. Detection of Borrelia burgdorferi in ticks by species-specific amplification of the flagellin gene. Am J Trop Med Hyg. 1992;47:730-41. https:/ / doi.org/10.4269/ajtmh.1992.47.730

37. Bates D, Maechler M, Bolker B, Walker S. lme4: Linear mixed-effects, models using Eigen and S4. 2020 [cited 2020 Jun 13]. https:/ / tinyurl.com/lme42020

38. Fox J, Weisberg S. An R companion to applied regression. 3rd ed. Thousand Oaks (CA): Sage Publications, Inc.; 2019.
39. Johnson JB, Omland KS. Model selection in ecology and evolution. Trends Ecol Evol. 2004;19:101-8. https://doi.org/10.1016/j.tree.2003.10.013

40. Lenth RV. Least-squares means: the R package lsmeans. J Stat Softw. 2016;69:1-33. https://doi.org/10.18637/ jss.v069.i01

41. Elston DA, Moss R, Boulinier T, Arrowsmith C, Lambin X. Analysis of aggregation, a worked example: numbers of ticks on red grouse chicks. Parasitology. 2001;122:563-9. https://doi.org/10.1017/S0031182001007740

42. Huntley SJ, Mahlberg M, Wiegand V, van Gennip Y, Yang H, Dean RS, et al. Analysing the opinions of UK veterinarians on practice-based research using corpus linguistic and mathematical methods. Prev Vet Med. 2018;150:60-9. https://doi.org/10.1016/j.prevetmed.2017.11.020

43. James MC, Bowman AS, Forbes KJ, Lewis F, McLeod JE, Gilbert L. Environmental determinants of Ixodes ricinus ticks and the incidence of Borrelia burgdorferi sensu lato, the agent of Lyme borreliosis, in Scotland. Parasitology. 2013;140:23746. https://doi.org/10.1017/S003118201200145X

44. Hanincová K, Schäfer SM, Etti S, Sewell HS, Taragelová V, Ziak D, et al. Association of Borrelia afzelii with rodents in Europe. Parasitology. 2003;126:11-20. https://doi. org/10.1017/S0031182002002548

45. Milne A. Pasture improvement and the control of sheep tick (Ixodes ricinus L.) Ann Appl Biol. 1948;35:369-78. https://doi.org/10.1111/j.1744-7348.1948.tb07381.x

46. Owen NW, Kent M, Dale P. Ecological effects of cultivation on the machair sand dune systems of the Outer Hebrides, Scotland. J Coast Conserv. 2000;6:155-70. https:/ / doi.org/ 10.1007/BF02913812

47. Gilbert L, Maffey GL, Ramsay SL, Hester AJ. The effect of deer management on the abundance of Ixodes ricinus in Scotland. Ecol Appl. 2012;22:658-67. https://doi.org/ 10.1890/11-0458.1

48. Hofmeester TR, Sprong H, Jansen PA, Prins HHT, van Wieren SE. Deer presence rather than abundance determines the population density of the sheep tick, Ixodes ricinus, in Dutch forests. Parasit Vectors. 2017;10:433. https:/ / doi.org/10.1186/s13071-017-2370-7

49. Mysterud A, Easterday WR, Stigum VM, Aas AB, Meisingset EL, Viljugrein H. Contrasting emergence of Lyme disease across ecosystems. Nat Commun. 2016;7:11882. https://doi.org/10.1038/ncomms11882

Address for correspondence: Caroline Millins, Department of Livestock and One Health, Institute of Infection, Veterinary and Ecological Sciences, Leahurst Campus, University of Liverpool, Neston, CH64 7TE, UK; email: Caroline.Millins@ Liverpool.ac.uk 